\title{
CAMPUR KODE DALAM IKLAN PENAWARAN BARANG DI FORUM JUAL BELI ONLINE FACEBOOK KOTA PALANGKA RAYA (KAJIAN SOSIOLINGUISTIK)
}

\author{
Noviasi ${ }^{1}$, Linggua Sanjaya Usop ${ }^{2}$, Indra Perdana ${ }^{3}$, Petrus Poerwadi ${ }^{4}$, Paul Diman ${ }^{5}$, dan \\ Lazarus Linarto ${ }^{6}$ \\ Universitas Palangka Raya, Indonesia \\ noviasi2611@gmail.com
}

\begin{abstract}
ABSTRAK
Tujuan penelitian ini adalah mendeskripsikan campur kode dalam forum jual beli online Facebook di kota Palangka Raya. Masalah yang akan digali dalam penelitian ini adalah: (1) Bagaimana bentuk campur kode dalam iklan penawaran barang di forum jual beli online Facebook kota Palangka Raya (2) Apa penyebab terjadinya campur kode dalam iklan penawaran barang di forum jual beli online Facebook kota Palangka Raya.

Metode penelitian yang digunakan dalam penelitian ini adalah metode penelitian kualitatif deskriptif. Data yang digunakan dalam penelitian ini adalah kata, frasa, dan klausa/kalimat pada status pedangang online dalam forum jual beli online di kota palangka raya di Facebook. Sumber data yang dipakai adalah hasil ScreenShoot pada status penjual online dalam forum jual beli online. Teknik pengumpulan data dilakukan dengan teknik studi pustaka, membaca, mencatat dan dimasukkan pada data penelitian. Teknik analisis data menggunakan teknik interpretasi teks.

Hasil dari penelitian ini menunjukkan bahwa terdapat 50 data kutipan bentuk campur kode sering ditemukan dalam status penjual online dalam forum jual beli di kota Palangka Raya di Facebook terdapat 50 kutipan dengan rincian campur kode dalam bentuk kata 37 kata, campur kode dalam bentuk frasa 19 frasa, campur kode dalam bentuk kata ulang 1 kata ulang, dan campur kode dalam bentuk klausa 1 klausa. Jadi dapat simpulkan bahwa bentuk campur kode yang paling banyak ditemukan dalam forum jual beli online Facebook di kota Palangka Raya adalah bentuk kata dan frasa. Faktor penyebab yang melatarbelakangi campur kode dapat dibedakan menjadi dua yaitu, latar belakang non kebahasaan atau sikap (atitudinal type) dan latar belakang kebahasaan (linguistic type). Faktor penyebab terjadinya campur kode dalam forum jual beli online di kota Palangka Raya di Facebook berjumlah 50 data, faktor campur kode non kebahasaan 24 data dengan rincian (a) need for synonym 2 data, (b) social value 22 data. Faktor kebahasaan sebanyak 28 data dengan rincian (a) low frequenchy of word 2 data, (b) oversight 2 data dan (c) end (purpose and goal) 24 data. Jadi dapat disimpulkan bahwa penyebab penjual online melakukan campur kode adalah social value yaitu penutur segaja menggunakan bahasa asing dalam tuturannya agar terlihat seperti orang yang terpelajar, modern, berwawasan luas dan hebat dan penyebab selajutnya adalah end (purpose and goal) yaitu penutur ingin menerangkan, membujuk, dan meyankikan pembeli agar barang yang dijual menarik perhatian pembeli.

Kata Kunci: Campur Kode, Sosiolinguistik, Jual Beli Online, Facebook.
\end{abstract}




\section{ABSTRACT}

The purpose of this study is to describe code mixing in the Facebook online buying and selling forum in the city of Palangka Raya. The problems that will be explored in this research are: (1) What is the form of code mixing in the advertisement of goods offerings in the online buying and selling forum for Facebook, Palangka Raya (2) What is the cause of code mixing in the advertisement for goods offerings in the online buying and selling forum for Facebook, Palangka Raya.

The research method used in this research is descriptive qualitative research method. The data used in this study are words, phrases, and clauses/sentences on the status of online traders in online buying and selling forums in the city of Palangkaraya on Facebook. The data source used is the ScreenShoot results on the status of online sellers in online buying and selling forums. The data collection technique was carried out by means of library research, reading, taking notes and entering the research data. The data analysis technique uses text interpretation techniques.

The results of this study indicate that there are 50 citation data in the form of codemixing often found in the status of online sellers in buying and selling forums in the city of Palangka Raya on Facebook, there are 50 quotations with code-mixing details in the form of 37 words, code-mixing in the form of 19 phrases, mix code in the form of repeat 1 word again, and mix code in the form of clause 1 clause. So it can be concluded that the most common forms of code mixing found in Facebook's online buying and selling forums in Palangka Raya are words and phrases. The causative factors behind code mixing can be divided into two, namely, non-linguistic background or attitude (atitudinal type) and linguistic background (linguistic type). The factors causing code mixing in online buying and selling forums in the city of Palangka Raya on Facebook are 50 data, non-linguistic code-mixing factors are 24 data with details of (a) need for synonym 2 data, (b) social value 22 data. The linguistic factor consists of 28 data with details of (a) low frequency of word 2 data, (b) oversight 2 data and (c) end (purpose and goal) 24 data. So it can be concluded that the cause of online sellers doing code mixing is social value, namely speakers deliberately use foreign languages in their speech to make them look like educated, modern, broad-minded and great people and the next cause is end (purpose and goal), i.e. speakers want to explain, persuade, and convince buyers that the goods being sold attract the attention of buyers.

Keywords: Code Mixing, Sociolinguistics, Online Buying and Selling, Facebook. 


\section{PENDAHULUAN}

Bahasa memegang peranan penting dalam kehidupan masyarakat yaitu sebagai sarana komunikasi. Mengingat pentingnya bahasa dalam menjalankan berbagai aktivitas sehari-hari tentu masyarakat akan terlibat komunikasi, baik bertindak sebagai pembicara maupun sebagai penyimak. Peristiwa komunikasi yang berlangsung tersebut dapat dijadikan tempat atau mengungkapkan ide, gagasan, isi, pikiran, maksud, realitas dan sebagainya. Dengan demikian, tanpa adanya sesuatu dalam situasi berbahasa itu yang menuntut percampuran bahasa.

Chaer dan Agustina (1995:14) fungsi utama bahasa adalah sebagai alat komunikasi. Komunikasi dapat dibedakan menjadi non-verbal dan verbal. Komunikasi non-verbal berlangsung tanpa suara, misalnya gerakan tangan, peluit, tanda-tanda, kedipan, lampu, dan sebagainya, sedangkan komunikasi verbal adalah komunikasi yang menggunakan bahasa sebagai alatnya baik media lisan maupun tulis. Bukan hanya itu saja tetapi bahasa juga digunakan untuk mengekspesikan pikiran dan perasaannya, proses tersebut menyediakan bahasa sebagai media penyampaian buah pikiran seseorang agar diketahui dan memperoleh respon dari orang lai Saat melakukan transaksi jual beli, masyarakat sering menyisipkan dua unsur bahasa atau bahkan lebih dalam setiap tuturan. Hal ini terjadi tanpa disegaja atau disadari dan sudah menjadi kebiasaan serta pengaruh situasi informal. Percampuran bahasa yang dipengaruhi oleh bahasa daerah maupun bahasa asing tidak menutup kemungkinan akan terjadi peralihan dan percampuran kode.

Berdasarkan uraian di atas, peneliti tertarik untuk meneliti Campur Kode Dalam Iklan Penawaran Barang di Forum Jual beli Online Facebook Kota Palangka Raya (Kajian Sosiolinguistik). Adapun alasan peneliti memilih penelitian Campur Kode Dalam Iklan Penawaran Barang di Forum Jual beli Online Facebook Kota Palangka Raya (Kajian Sosiolinguistik). Karena sepengetahuan peneliti belum pernah ada yang melakukan penelitian ini, maka dari itu peneliti tertarik untuk menelitinya.

\section{Campur Kode}

Campur kode adalah penggunaan bahasa dengan mencampur dua atau lebih bahasa dalam suatu tindak bahasa tanpa ada sesuatu dalam situasi bahasa itu. Misalnya, seseorang penutur menggunakan bahasa Indonesia dengan menyisipkan kata-kata dari bahasa asing ke dalam bahasa tersebut. Penggunaan bahasa seperti ini dapat dikatakan campur kode.

Campur kode adalah suatu keadaan berbahasa bilamana orang mencampur dua atau lebih bahasa dengan saling memasukan unsur-unsur bahasa yang satu kedalam bahasa yang lain, unsur-unsur yang menyisipkan tidaklah mempunyai fungsi sendiri, Suwito (1996:68).

Campur kode adalah penggunaan satuan bahasa dari satu bahasa ke bahasa lain untuk memperluas gaya bahasa atau ragam bahasa, termasuk di dalamnya pemakaian kata, frasa, klausa, idiom, dan sapaan, Kridalaksana (2008:40). Menurut Nababan (1993:32) campur kode adalah situasi ketika orang mencampur dua bahasa atau lebih atau bahasa yang memerlukan pencampuran bahasa. Dalam keadaan seperti itu hanya relaksasi pembicara atau kebiasaan yang dipatuhi.

\section{Bentuk-Bentuk Campur Kode}

Berdasarkan unsur-unsur kebahasaan yang terlibat di dalamnya, Suwito (1996: 92) membedakan bentuk campur kode menjadi beberapa macam antara lain:

a. Penyisipan unsur-unsur yang berwujud kata 
Kata merupakan unsur terkecil dalam pembentukan kalimat yang sangat penting perananya dalam tata bahasa, yang dimaksud kata adalah satuan bahasa yang berdiri sendiri, terdiri dari morfem tunggal atau gabungan morfem.

b. Penyisipan unsur-unsur yang berwujud frasa

Campur kode pada tataran merupakan campur kode yang setingkat lebih rendah dibandingkan dengan campur kode pada tataran klausa. Frasa adalah gabungan dua kata atau lebih yang sifatnya tidak prediktif, gabungan itu dapat rapat dan dapat renggang.

c. Penyisipan unsur-unsur yang berwujud bentuk baster

Baster merupakan hasil perpaduan dua unsur bahasa yang berbeda membentuk satu makna.

d. Penyisipan unsur-unsur yang berwujud perulangan kata

Pengulangan kata merupakan kata yang terjadi sebagai akibat reduplikasi.

e. Penyisipan unsur-unsur yang berwujud ungkapan atau idiom

Idiom merupakan konstruksi dari unsur-unsur yang saling memilih, masing-masing anggota mempunyai makna yang ada hanya karena bersama yang lain atau dengan pengertian lain idiom merupakan konstruksi yang maknanya tidak sama dengan gabungan makna anggota-anggotanya.

f. Penyisipan unsur-unsur yang berwujud klausa

Klausa sebagai satuan gramatikal yang berupa kelompok kata yang sekurangkurangnya terdiri dari subjek dan predikat serta mempunyai potensi untuk menjadi kalimat. Campur kode dalam tataran klausa berada pada tataran tertinggi. Klausa terdiri dari subjek, dan predikat baik disertai objek, pelengkap, keterangan ataupun tidak.

\section{Penyebab Terjadinya Campur Kode}

Suwito (dalam Maulidini, 2007: 37-43) memaparkan dua hal yang paling melatarbelakangi penggunaan campur kode. Latar belakang tersebut dapat dibedakan menjadi latar belakang non kebahasaan atau sikap (atitudinal type) dan latar belakang kebahasaan (linguistic type).

\section{a. Faktor non kebahasaan (atitudinal type)}

1) Need for synonym maksudnya adalah penutur menggunakan bahasa lain untuk lebih memperhalus maksud tuturan.

2) Sosial value, yaitu penutur sengaja mengambil kata dari bahasa lain dengan mempertimbangkan faktor sosial. Pada kasus disini penutur cenderung bercampur kode dengan bahasa asing dengan maksud menunjukkan bahwa penutur merupakan seseorang yang berpendidikan dan modern sehingga dalam berkomunikasi dengan lawan tutur banyak menyisipkan kata atau istilah dalam bahasa asing.

3) Perkembangan dan perkenalan dengan budaya baru.

Hal ini terjadi faktor pendorong munculnya campur kode oleh penutur. Misalnya dalam bidang penjualan banyak penutur memakai bahasa asing padahal bahasa asing tersebut bukanlah bahasa asli penutur.

\section{b. Faktor kebahasaan (linguistik type)}

Latar belakang kebahasaan yang menyebabkan seseorang melakukan campur kode disebabkan oleh hal-hal sebagai berikut:

1) Low frequency of word, yaitu karena kata-kata dalam bahasa asing tersebut lebih mudah diingat dan lebih stabil maknanya.

2) Pernicious humonity, maksudnya adalah jika penutur menggunakan kata dari bahasanya sendiri maka kata tersebut dapat menimbulkan masalah homonim yaitu makna ambigu.

3) Oversight, yaitu keterbatasan kata-kata yang dimiliki oleh bahasa penutur. 
End (purpose and goal), yaitu akibat atau hasil yang dikehendaki. End (tujuan) meliputi membujuk, dengan menyakinkan, meneerangkan. Untuk mencapai hasil tersebut penutur harus menggunakan campur kode.

\section{METODE PENELITIAN}

Penerapan suatu teori terhadap suatu permasalahan diperlukan metode yang dianggap relevan dan dapat membantu membatu permasalahannya. Metode penelitian yang digunakan pada campur kode dalam iklan penawaran barang di forum jual beli online Facebook kota Palangka Raya bersifat deskriptif analisis pendekatan kualitatif, yaitu penelitian yang diambil data kemudian diambil kesimpulannya.

Berdasarkan hasil analisis bentuk dan penyebab campur kode, di Facebook pada forum jual beli maka keseluruhan data yang di peroleh adalah 100 data. Berdasarkan penelitian yang telah di teliti oleh peneliti dalam campur kode sebagai berikut. Campur kode sering ditemukan dalam postingan penjual online di forum jual beli di kota Palangka Raya di Facebook sebanyak 57 data. Faktor penyebab penggunaan campur kode di postingan penjual online di Facebook sebanyak 50 data. Data tersebut diperoleh dari tanggal 01 Juli - 22 Juli 2021.

Dalam penelitian ini menggunakan metode dokumentasi, peneliti gunakan untuk memperoleh data yang benar-benar valid dan memang dibutuhkan. Dalam penelitian ini tehnik dokumentasi (sreenshoot) digunakan untuk mengumpulkan data mengenai postingan penjual di grub jual beli online di Facebook untuk diidentifikasi mengenai bentuk dan penyebab campur kode.

Studi pustaka adalah prosedur yang digunakan dalam penelitian ini. Prosedur ini digunakan untuk mengetahui campur kode dalam transaksi jual beli online di Facebook. Adapun prosedur pengumpulan data ini adalah peneliti akan me-screenshot semua postingan orang-orang yang berjualan online pada forum jual beli online Facebook di kota Palangka Raya yang mengandung campur kode pada jejaring media sosial Facebook, lalu di transkripkan, kemudian dideskripsikan, selanjutnya dilakukan analisis, kemudian diklasifikasi keseluruhan data yang telah ditemukan.

Pemeriksaan keabsahan data dalam penelitian ini, peneliti menggunakan teknik triangulasi. Bogdam dan Biklen (1982:1045) mengatakan bahwa analisis data kualitatif merupakan upaya yang dilakukan dengan cara bekerja dengan data, mengorganisasikan data, memilah-milah menjadi satuan yang dapat satuan-satuan yang dapat diceritakan kepada orang lain, untuk itu dalam penelitian ini peneliti menggunakan campur kode dalam transaksi jual beli online pada forum jual beli Facebook di Kota Palangka Raya dalam bentuk kualitatif. Analisis data dalam penelitian ini adalah data yang diperoleh dilihat berdasarkan hasil mengamati, membaca, dan mendeskripsikan, kemudian hasil deskripsi dikumpulkan, lalu data dikelola dengan menggunakan kriteria kualitatif dan terakhir dibuatkan kesimpulan.

Triangulasi sumber menurut Sugiyono (2013:330) triangulasi diartikan sebagai tehnik pengumpulan data yang bersifat menggabungkan data dari berbagai tehnik pengumpulan data dan sumber data yang telah ada. Dalam penelitian ini, peneliti menggunakan triangulasi tehnik. Menurut Sugiyono (2013:330) triangulasi tehnik berarti peneliti menggunakan tehnik pengumpulan data yang berbeda-beda untuk mendapatkan data dari sumber data yang sama.

Triangulasi data digunakan untuk menguji data yang dilakukan dengan cara mengecek data yang telah diperoleh. Data yang diperoleh tersebut dideskripsikan, dikategorikan, dan dianalisis mana pandangan yang sama dan spesifik dari sumber-sumber tersebut. Penelitian ini sumber yang diambil adalah dari buku materi dan narasumber 
Volume 2, Nomor 2, Desember 2021

ISSN: $2746-7708$

Enggang: Jurnal Pendidikan, Bahasa, Sastra, Seni, dan Budaya

campur kode dalam iklan penawaran barang di forum jual beli online Facebook kota Palangka Raya. 
Enggang: Jurnal Pendidikan, Bahasa, Sastra, Seni, dan Budaya

\section{HASIL PENELITIAN}

Berikut ini adalah paparan hasil penelitian campur kode dan penyebab terjadinya campur kode.

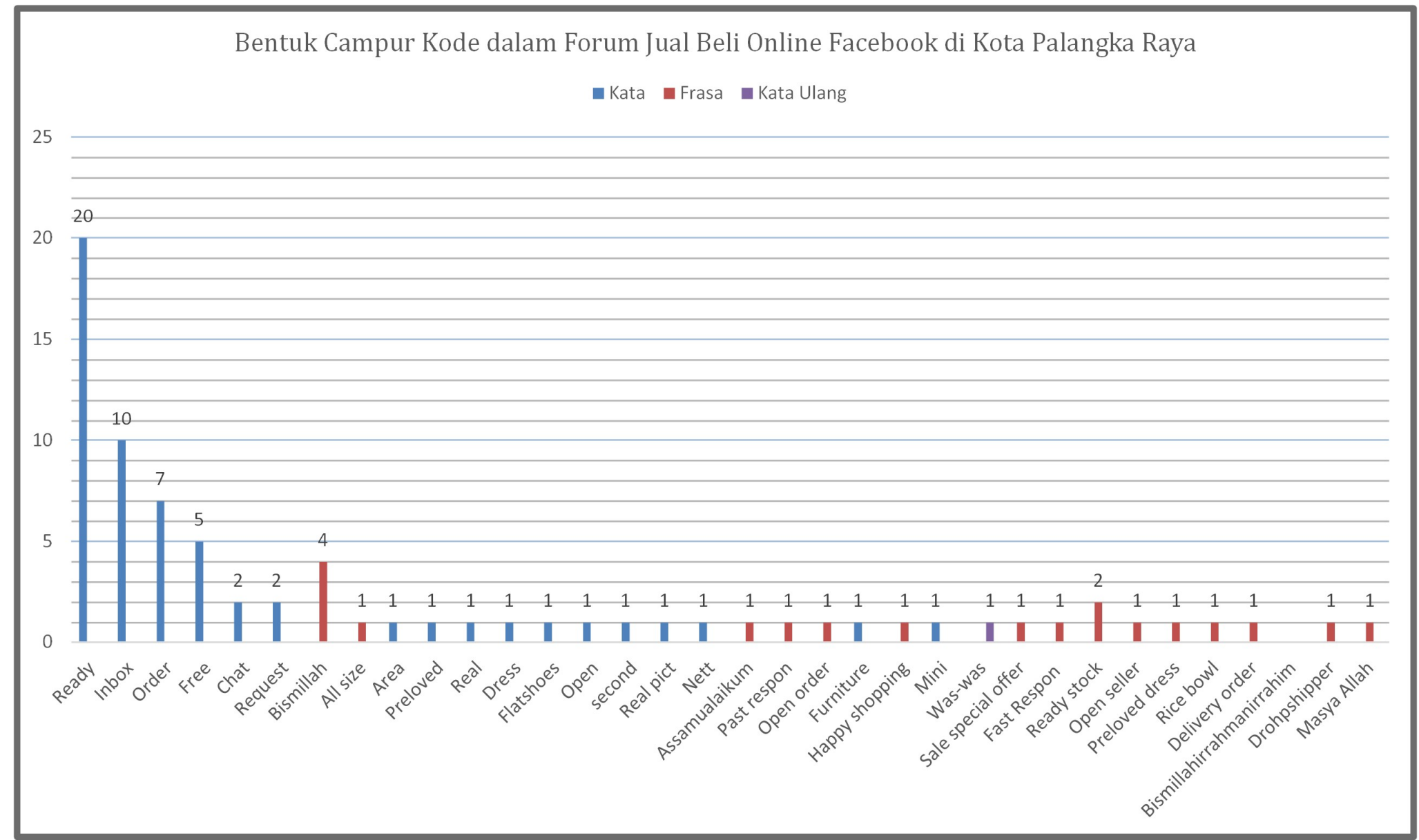


Berdasarkan data, campur kode yang terdapat 57 data yang dimulai dari tanggal 01 Juli 2021 sampai 21 Juli 2021 pada forum jual beli online Facebook di kota Palangka Raya. Maka peneliti mendapatkan hasil penelitian berupa campur kode dalam bentuk kata berjumlah 57 data dengan rincian campur kode dalam bentuk kata 37 kata, campur kode dalam bentuk frasa 19 frasa, dan campur kode dalam bentuk kata ulang 1 kata ulang.

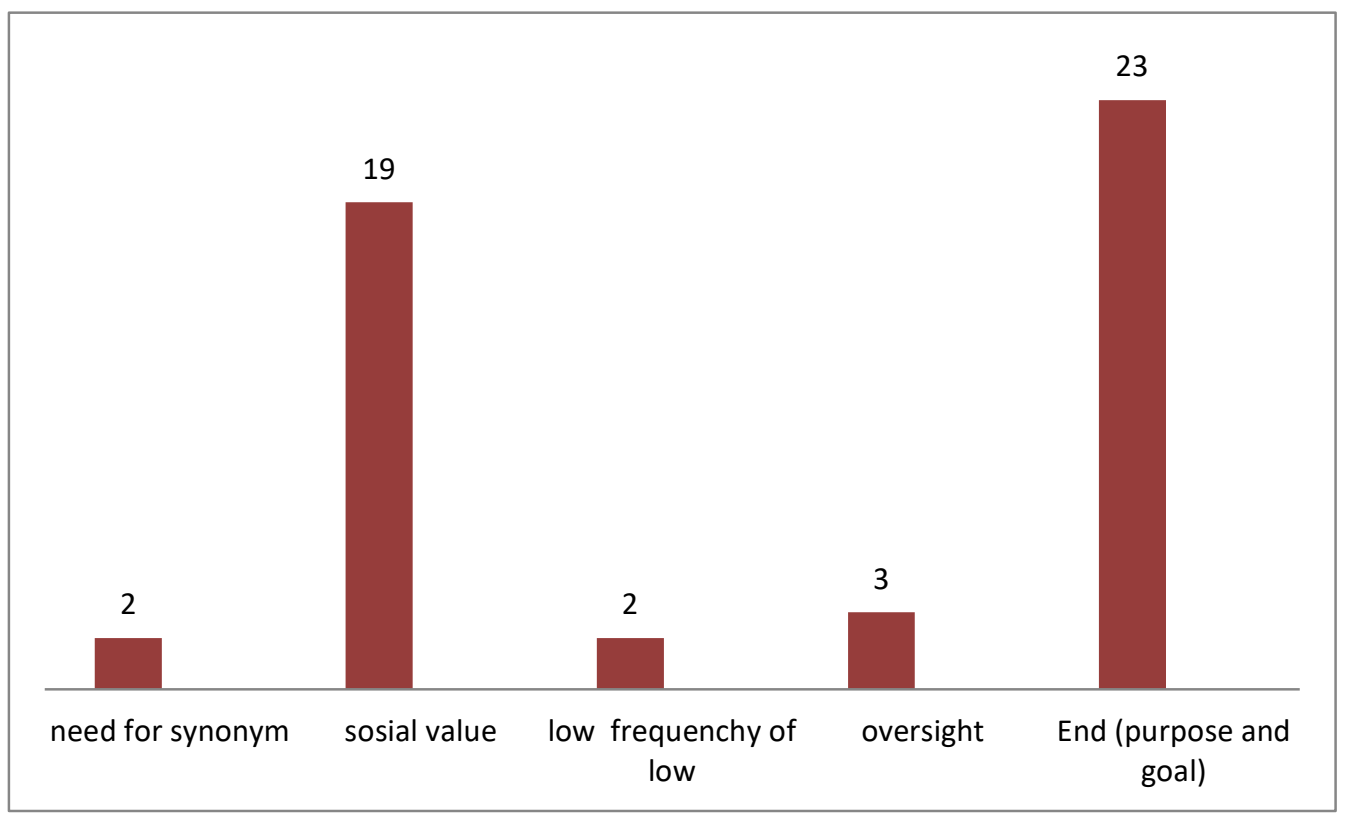

Gambar 2. Data Penyebab Campur Kode dalam Forum Jual Beli Online Facebook di Kota Palangka Raya

Berdasarkan data, penyebab terjadinya campur kode yang terdapat pada 50 data dimulai dari 01 Juli 2021 sapai 21 Juli 2021 pada forum jual beli online Facebook di kota Palangka Raya. Maka peneliti mendapatkan hasil penelitian sebanyak 50 data dengan rincian, campur kode non kebahasaan 24 data dengan rincian (a) need for synonym 2 data, (b) social value 22 data. Faktor kebahasaan sebanyak 28 data dengan rincian (a) low frequenchy of word 2 data, (b) oversight 2 data dan (c) end (purpose and goal) 24 data.

\section{Bentuk Penggunaan Campur Kode Dalam Forum Jual Beli Online Facebook di Kota Palangka Raya (Kajian Sosiolinguistik)}

Berdasarkan unsur-unsur kebahasaan yang terlibat di dalamnya, Suwito (1996: 92) membedakan bentuk campur kode menjadi beberapa macam antara lain:

a. Penyisipan unsur-unsur yang berwujud kata

Kata merupakan unsur terkecil dalam pembentukan kalimat yang sangat penting perananya dalam tata bahasa, yang dimaksud kata adalah satuan bahasa yang berdiri sendiri, terdiri dari morfem tunggal atau gabungan morfem.

Data (1): "Ready ya, Dress serba 40 ribu. Ambil banyak ada harga diskon, masih banyak model lainnya ya,, kualitas mantul \& dijamin antivirus. Beli 1 pke ongkir, beli 2 atau 3 gratis ongkir. Minat chat Wa.0853-9231-8668/inbox". (Kamis, 01 Juli 2021 pukul 10.02 WIB). 
Pada data (1) terdapat campur kode dalam bentuk kata tampak pada postingan Mizwari Dwi Ramadhani yaitu menyisipkan kata bahasa Inggris pada postingannya. Hal ini terlihat pada kata ready yang jika diartikan dalam bahasa Indonesia adalah siap, dress yang berarti gaun, dan inbox yang berarti kotak masuk.

Data (2): "Realll testi ya say, pemakaian pelanggan ulun, yuk yang mau glow up bareng-barengg cus di orderrr". (Kamis, 01 Juli 2021).

Pada data (2) terdapat campur kode dalam bentuk kata tanpak pada postingan akun Safira Fira yang menyisipkan kata bahasa Inggris ke dalam postinganya. Hal ini terlihat pada kata real yang berarti nyata, glow up yang berarti bersinar dan order yang berarti memesan.

Data (3): "Ready tali masker masih ada model lain bisa request panjang tali dan warna, selama stok bahan masih ada. Ongkir sesuai jarak minat langsung inbox atau wa 082153259240”. (Jumat, 02 Juli 2021).

Pada data (3) terdapat campur kode dalam bentuk kata tanpak pada postingan pemilik akun bernama Sumber Berkah yang menyisipkan kata bahasa Inggris ke dalam postingannya. Hal ini terlihat pada kata ready yang berarti siap dan request yang berarti meminta, dan inbox yang berarti kotak masuk.

Data (4): "Hp seken Vivo Y19 Ram 6/128 ORI Lengkap. Harga: 1.850.000 Nett. Alamat: KT PHONE CELL Jalan Kinibalu Depan Bengkel Kilat Motor, Sebelah Pengaringan Hp/;082149444300. (Jumat,02 Juli 2021).

Pada data (4) terdapat campur kode dalam bentuk kata tanpak pada postingan pemilik akun Arifin Alfin yang menyisipkan kata bahasa Inggris dalam postingannya. Hal ini tanpak pada kata nett yang berarti bersih.

Data (5): "Ready stok banyak bisa di antar atau ambil sendiri. Warna merah, putih, navy, biru muda, cream, dan abu". (Sabtu,03 Juli 2021).

Pada data (5) terdapat campur kode dalam bentuk kata tanpak pada postingan pemilik akun Irawati yang meyisipkan kata bahasa Inggris ke dalam.

b. Penyisipan unsur-unsur yang berwujud frasa

Campur kode pada tataran merupakan campur kode yang setingkat lebih rendah dibandingkan dengan campur kode pada tataran klausa. Frasa adalah gabungan dua kata atau lebih yang sifatnya tidak prediktif, gabungan itu dapat rapat dan dapat renggang.

Data (40): "Bismillah. Habisin stok yg lengan pendek yaa, harga Cuma 20rb aja. Area palangkaraya siap antar, ongkir menyesuaikan jarak...Terimakasih. (Jumat, 02 Juli 2021).

Pada data (40) terdapat penyisipan campur kode dalam bentuk frasa tanpak pada postingan pemilik akun Yana Nursiana yang menyisipkan frasa bahasa Arab dalam postingannya yaitu Bismillah yang berarti dengan nama Tuhan.

Data (41): “Assalamualikum Ladies. Mulai Hari ini setiap transaksi 1 mukena dapat free 1 masker Ttauis. Promo hanya berlaku samapai 31 Juli 2021. Info dan detail langsung bisa inbox/wa 0812544637008. Koleksi mukena lainnya bisa datang 
langsung ke Toko Tatuis Mukena Jl. Jati No.43 Palangka Raya atau cek ig tatuispraya. Happy Shopping. Toko buka senin-sabtu ja 10.00-16.00”. (Minggu 04 Juli 2021).

Pada data (41) terdapat penyisipan campur kode dalam bentuk kata dan campur kode dalam bentuk frasa terdapat pada postingan pemilik akun Ttauispraya yang menyisipkan frasa bahasa Arab yaitu Assalamualikum yang berarti semoga keselamatan terlimpah padamu, dan frasa bahasa Inggris yaitu Happy Shopping yang berarti selamat berbelanja.

Data (42): "Open order stelan Import lagi ya bund Tersedia dengan dua warna. Area palangka raya bisa cod buruan di order yaa bund sebelum kehabisan minat inbox". (Minggu, 04 Juli 2021)

Pada data (42) terdapat penyisipan campur kode berbentuk frasa tanpak pada postingan pemilik akun Apriyanti yang menyisipkan frasa dan kata bahasa Inggris dalam postinganya. Hal ini tampak pada frasa bahasa Inggris open order yang berarti pesan.

c. Penyisipan unsur-unsur yang berwujud perulangan kata

Pengulangan kata merupakan kata yang terjadi sebagai akibat reduplikasi.

Data (59): "Ready stock, awet, bisa dipakai setiap hari, tidak bikin gatal dan alergi di kulit, cocok untuk kulit yang senditif, warna dan model menyerupai emas asli cocok sebagai pengganti emas untuk berpergian kemana mana tanpa harus waswas, bisa langsung ke toko atau di antar dan bisa milih-milih langsung di rumah tho beb-:!!!! Terima open seller dan grosir minat silahkan japri “. (Minggu, 12 Juli 2021).

Pada data (59) terdapat penyisipan campur kode dalam kata ulang tanpak pada postingan pemilik akun Habibah Az Zahra yang menyisipkan frasa dan kata ualng dalam postingannya. Campur kode dalam bentuk kata ulang yaitu was-was.

\section{Penyebab Terjadinya Campur Kode Dalam Forum Jual Beli Online Facebook di Kota Palangka Raya}

Penyebab terjadinya campur kode dalam forum jual beli online terbagi menjadi dua, yaitu faktor non kebahasaan dan faktor kebahasaan.

Faktor non kebahasaan meliputi:

a. Need for synonym maksudnya adalah penutur menggunakan bahasa lain untuk lebih memperhalus maksud tuturan.

Data (1): "Ready laptop second harga murah, kualitas oke, bergaransi siap pakai. Yukk yg mau tanya tanya bisa langsung inbox atau hubungi. Wa 082350374401”. (Jumat, 09 Juli 2021).

Pada data tersebut peneliti mengklasifikasikan kata second pada akun Amita Sari ke dalam campur kode non kebahasaan need for synonym karena tujuan penutur menggunakan bahasa Inggris yaitu second untuk memperhalus tuturannya. Seperti pada tuturan "ready laptop second harga murah" yang maksudnya "ada laptop bekas harga murah". Kata bekas terdengar lebih kasar. Oleh Karen aitu penutur memperhalus lagi tuturannya dengan menggunakan kata second. 
Data (2): "Preloved masih layak pakai semua, kotor karna lama tersipan aja, bisa diantarkan gratis ongkir”. (Senin,13 Juli 2021).

Pada data tersebut peneliti mengklasifikan kata preloved pada akun Rini Mariani ke dalam faktor penyebab campur kode non kebahasaan need for synonym karena penutur ingin memperhalus tuturannya.

b. Sosial value

Penutur sengaja mengambil kata dari bahasa lain dengan mempertimbangkan faktor sosial. Pada kasus disini penutur cenderung bercampur kode dengan bahasa asing dengan maksud menunjukkan bahwa penutur merupakan seseorang yang berpendidikan dan modern sehingga dalam berkomunikasi dengan lawan tutur banyak menyisipkan kata atau istilah dalam bahasa asing.

Data (3): "Ready ya, Dress serba 40 ribu. Ambil banyak ada harga diskon, masih banyak model lainnya ya, kualitas mantul \& dijamin antivirus. Beli 1 pke ongkir, beli 2 atau 3 gratis ongkir. Minat chat Wa.0853-9231-8668/inbox". (Kamis, 01 Juli 2021 pukul 10.02 WIB).

Pada data tersebut faktor penyebab pemilik akun Mizwari Dwi Ramadhani melakukan campur kode karena faktor non kebahasaan sosial value karena dari penggunaan penyisipan bahasa asing terlihat bahwa penutur seperti seorang yang terpelajar ,modern dan dapat menarik perhatian orang lain supaya membeli barangnya. Hal ini terlihat pada tuturan ready, dress, inbox.

Data (4): "Hp seken Vivo Y19 Ram 6/128 ORI Lengkap. Harga: 1.850.000 Nett. Alamat: KT PHONE CELL Jalan Kinibalu Depan Bengkel Kilat Motor, Sebelah Pengaringan Hp/;082149444300. (Jumat,02 Juli 2021).

Pada data tersebut faktor penyebab pemilik akun Arifin Alfin menggunakan campur kode non kebahasaan sosial value pada kata nett karena pada tuturannya penutur menggunakan bahasa asing dengan tujuan agar terlihat seperti orang yang berpendidikan, modern dan berwawasan luas.

Data (5): "Bismillah. Habisin stok yg lengan pendek yaa, harga Cuma 20rb aja. Area palangkaraya siap antar, ongkir menyesuaikan jarak. Terimakasih. (Jumat, 02 Juli 2021).

Pada data tersebut faktor penyebab pemilik akun Yana Nursiana menggunakan campur kode non kebahasaan sosial value yaitu penutur segaja mengambil kata dari bahasa lain untuk menunjukkan bahwa penutur adalah orang yang taat agama. Terlihat pada penggunaan frasa Bismillah.

Faktor kebahasaan meliputi:

a. Low frequency of word, yaitu karena kata-kata dalam bahasa asing tersebut lebih mudah diingat dan lebih stabil maknanya.

Data (23): "Ready stok banyak bisa di antar atau ambil sendiri. Warna merah, putih, navy, biru muda, cream, dan abu”. (Sabtu,03 Juli 2021). 
Pada data tersebut faktor penyebab pemilik akun Irawati menggunakan campur kode kebahasaan low frequenchy of word, karena penutur menggunakan bahasa asing tersebut agar mudah diingat.

Data (24): "Salah beli, rok plisket jual rugi aja $27 \mathrm{~b}$ ready hitam, cream, navy, maroon. Plisket biasa bukan yang premium ini yg biasa di jual saa abg2 35-40. Aku jual 27 aja ya kalo minat bisa chat". (selasa, 06 Juli 2021)

Pada data tersebut peneliti mengklasifikasikan kata ready dan chat pada akun Maria Friskila ke dalam faktor penyebab campur kode kebahasaan low frequenchy of word, penggunaan kata ready dan chat oleh penutur karena kata tersebut lebih mudah diingat dan stabil maknanya.

b. Oversight, yaitu keterbatasan kata-kata yang dimiliki oleh bahasa penutur.

Data (25): "Ready di lapak uln di rajawali km 5,5 di saping gereja, Rambutan ponti s'ikat 15000 RB, Langsat ponti 18000 skilo 2 kilo 35000 Manggis $200001 \mathrm{~kg}$ Matoa Papuan $1 \mathrm{~kg} 50000$ yg minat bisa langsung ke lapak uln, maaf engga bisa ngantar". (Selasa, 06 Juli 2021).

Pada data tersebut peneliti mengklasifikasikan kata ready pada akun Siti Aisyah ke dalam faktor penyebab campur kode non kebahasaan oversight. Karena pada tuturannya penutur hanya menggunakan kata ready dengan alasan keterbatasan kata-kata dalam postingan penjualan.

Data (26): "Ready cuman 20 ribu bahan rayon Bisa diantar atau diambil sendiri. Jln karanggan". (Rabu, 07 Juli 2021).

Pada data tersebut peneliti mengklasifikasikan kata ready pada akun Irawati ke dalam faktor penyebab campur kode non kebahasaan oversight. Karena pada tuturannya penutur hanya menggunakan kata ready dengan alasan keterbatasan kata-kata dalam postingan penjualan.

Data (27): “Open po 5_7hari”. (Jumat,09 Juli 2021).

Pada data tersebut peneliti mengklasifikasikan kata open pada akun Mimiy Naufal ke dalam faktor penyebab campur kode non kebahasaan oversight. Karena pada tuturannya penutur hanya menggunakan kata open dengan alasan keterbatasan kata-kata dalam postingan penjualan.

c. End (purpose and goal)

End (purpose and goal) yaitu akibat atau hasil yang dikehendaki. End (tujuan) meliputi membujuk, dengan menyakinkan, meneerangkan. Untuk mencapai hasil tersebut penutur harus menggunakan campur kode.

Data (28): "Realll testi ya say, pemakaian pelanggan ulun, yuk yang mau glow up bareng-barengg cus di orderrr". (Kamis, 01 Juli 2021).

Pada data tersebut faktor penyebab pemilik akun Safira Fira melakukan campur kode karena faktor kebahasaan End (purpose and goal) karena pada tuturannya penutur ingin menyakinkan orang lain bahwa produk yang dijualnya sesuai dengan asli. Hal ini tampak pada kata real 
Data (29): "Super SALE Special OFFER Semua 35.000, Hak tahu/heels, Flatshoes, sandal teplek. Alamat jln Hiu putih raya toko pagar hitam (tepat di samping INDOMARET). (Kamis, 01 Juli 2021).

Pada data tersebut faktor penyebab pemilik akun Tamara Indriani menggunakan campur kode faktor kabahasaan end (purpose and goal) pada tuturannya karena penutur segaja menggunakan kata bahasa asing telihat pada kata sale special offer, dengan tujuan menerangkan mengenai barang yang dijual penutur agar menarik minat calon pembeli sehingga pembeli tertarik untuk membeli barang tersebut.

\section{SIMPULAN}

Berdasarkan hasil penelitian dan juga pembahasan yang terdapat dalam bab sebelumnya tentang campur kode dalam forum jual beli online Facebook di Kota Palangka Raya, dapat disimpulkan sebagai berikut.

Campur kode sering ditemukan dalam status penjual online dalam forum jual beli di kota Palangka Raya di Facebook terdapat 50 kutipan dengan rincian campur kode dalam bentuk kata 37 kata, campur kode dalam bentuk frasa 19 frasa, campur kode dalam bentuk kata ulang 1 kata ulang, dan campur kode dalam bentuk klausa 1 klausa.

Jadi dapat simpulkan bahwa bentuk campur kode yang paling banyak ditemukan dalam forum jual beli online Facebook di kota Palangka Raya adalah bentuk kata dan frasa.

Faktor penyebab yang melatarbelakangi campur kode dapat dibedakan menjadi dua yaitu, latar belakang non kebahasaan atau sikap (atitudinal type) dan latar belakang kebahasaan (linguistic type). Faktor penyebab terjadinya campur kode dalam forum jual beli online di kota Palangka Raya di Facebook berjumlah 50 data, faktor campur kode non kebahasaan 24 data dengan rincian (a) need for synonym 2 data, (b) social value 22 data. Faktor kebahasaan sebanyak 28 data dengan rincian (a) low frequenchy of word 2 data, (b) oversight 2 data dan (c) end (purpose and goal) 24 data. Jadi dapat disimpulkan bahwa penyebab penjual online melakukan campur kode adalah social value yaitu penutur segaja menggunakan bahasa asing dalam tuturannya agar terlihat seperti orang yang terpelajar,modern,berwawasan luas dan hebat dan penyebab selajutnya adalah end (purpose and goal) yaitu penutur ingin menerangkan,membujuk, dan meyankikan pembeli agar barang yang dijual menarik perhatian pembeli. 


\section{DAFTAR PUSTAKA}

Arikunto. 1990. Prosedur Penelitian Suatu Pendekatan Praktek. Jakarta: Rineka Cipta.

Arikunto. 2005. Metode Penelitian Kualitatif. Jakarta: Sagung Seto.

Bogdan, R. C. Biklen, S.K. 1982. Qualitative Research for Education: An Introduction to Theory and Method. Boston: Allyn and Bacon, inc. Budi Putra, Planet Internet Jaringan Pintar yang Mengubah Dunia (Tangerang: Logicom Publication, 2005), h 39.

Chaer, Abdul \& Leonie Agustina. 2010. Sosiolinguistik: Perkenalan Awal. Jakarta: PT Rineka Cipta.

1995. Sosiolinguistik: Suatu Pengantar. Jakarta: Rineka Cipta.

Jesse Failer, How to Do Everythung: Facebook Applications. (Amerika: MC Graw-Hill Companies, 2008), h 7.

Kentjono, Djoko. 1982. Dasar-Dasar Linguistik Umum. Jakarta: Fakultas Sastra UI

Khair, U., \& Misnawati, M. 2022. Indonesian language teaching in elementary school: Cooperative learning model explicit type instructions chronological technique of events on narrative writing skills from interview texts. Linguistics and Culture Review. 6, 172-184.

Kridalaksana, Harimurti. 1982. Kamus Linguistik. Jakarta: Gramedia. 2008. Kamus Linguistik. Jakarta: Gramedia Pustaka Utama.

Moleong, Lexi. 2005. Metodologi Penelitian Kualitatif. Bandung: PT. Remaja Rosdakarya.

Muhamad, Alimin. 2004. Etika dan Perlindungan Konsumen dalam Ekonomi Islam. Yogyakarta: BPFE

Nababan, P.W.J. 1984. Tuntunan Penyusunan Bahasa Indonesia. Bandung: Sinar Baru.

1993. Sosiolinguistik dan Pengajarannya dalam Pelba 2 (ed. Bambang Kaswarti Purwo). Jakarta: Lembaga Bahasa untuk Atmajaya

Natalia, Indri. 2020. Campur Kode Pada Akun Status Facebook Mahasiswa Program Studi Pendidikan Bahasa dan Sastra Indonesia. Skripsi. Universitas Palangka Raya. Palangka Raya. 
Nursaid dan Marjusman Maksan. 2002. “Sosiolinguistik” Buku Ajar. FBSS: UNP Press.

Pateda, Mansoer. 1987. Sosilinguistik. Bandung: Angkasa.

Perdana, I., \& Misnawati, M. P. (2019). Cinta dan Bangga Berbahasa Indonesia Di Perguruan Tinggi. SPASI MEDIA.

Poedjosoedarmo, S. 1978. Interferensi dan Integrasi dalam Situasi Keanekabahasaan. Jakarta: Pusat Pembinaan dan Pengembangan Bahasa.

Pramusuri, Fitri. 2015. "Alih Kode dan Campur Kode Pada Percakapan di Status Jejaring Sosial Facebook". Skripsi. Purwokerto: Fakultas Keguruan dan Ilmu Pendidikan.

Priyatna, Haris. 2009. Sukses Di Era Facebook: Kiat-kiat Memanfaatkan Media Sosial Untuk Kemenangan Gemilang. Bandung: How Press.Purwokerto: Universitas Muhammadiyah Purwokerto.

Saddhono, Kundharu. 2012. Pengantar Sosiolinguistik Teori dan Konsep Dasar. Surakarta: Program Buku Teks LPP UNS

Simatupang, R, R., Rohmadi, M., Saddhono, K. 2018. Tuturan dalam Pembelajaran Bahasa Indonesia (Kajian Sosiolinguistik Alih Kode dan Campur Kode. Kajian Lingistik dan Sastra, 3 (2), 119-130.

Sitepu, K. H. B., Poerwadi, P., \& Linarto, L. (2021). REALISASI ILOKUSI TINDAK TUTUR DIREKTIF DALAM DIALOG PROSES BELAJAR MENGAJAR MATA PELAJARAN BIOLOGI DI SMAK SANTO ALOYSIUS PALANGKA RAYA. ENGGANG: Jurnal Pendidikan, Bahasa, Sastra, Seni, dan Budaya, 2(1), 79-90.

Soeparno. 1993. Dasar-dasar Linguistik. Yogyakarta: Mitra Gama Widya

Subroto Edi, D. 2007. Pengantar Metode Penelitian Linguistik Struktural. Surakarta: Universitas Sebelas Maret Press.

Sugiyono. 2013. Metode Penelitian Pendidikan Pendekatan Kuantitatif, Kualitatif, dan R\&D. Bandung. Alfabeta.

Suwito. 1996. Pengantar Awal Sosiolinguistik (Teori dan Problem). Surakarta: Henary Offet.

Tololiju, Jolinda Amelia. 2018. "Campur Kode Pada Media Sosial Facebook”. Skripsi. Manado: Fakultas Ilmu Budaya.

Wahid Murni dan Nur Ali. Penelitian Tindakan Kelas Pendidikan Agama dan Umum dari Teori Menuju Praktek. (Malang: UM Press, 2008), hal. 49

Wijaya, I Dewa Putu; Rohmadi, Muhammad. 2006. Sosiolinguistik: Kajian Teori dan Analisis (ed. 1). Yogyakarta: Pustaka Pelajar. 